\title{
Correlations between estimating GFR methods and oncological outcomes during cancer chemotherapy
}

\section{Kanser kemoterapisi alan hastalarda tahmini GFR ölçüm metodlarının korelasyonu ve onkolojik sonuçlar ile ilişkisi}

\author{
Özlem Özkul ${ }^{1 *} \mathbb{D}$, Bayram Kızılkaya ${ }^{2}$ (D), Hüseyin Eren ${ }^{3}(\mathbb{D})$ Teslime Ayaz $^{2}$ (D), Cemil Bilir ${ }^{1}$ \\ ${ }^{1}$ Oncologist, Dept. of Oncology, Sakarya University, Sakarya, Turkey \\ 2 Internal Medicine Assistant, Dept. of İnternal Medicine, Recep Tayyip Erdoğan University, Rize, Turkey \\ ${ }^{3}$ Urology Assistant, Dept of Urology, Recep Tayyip Erdoğan University, Rize, Turkey \\ * Corresponding author: Özlem Özkul E-mail: drozlemozkul@yahoo.com.tr ORCID: 0000-0003-4413-0133 \\ Received: 19 December 2018 Accepted: 18 May 2019
}

\begin{abstract}
Background: Glomerular filtration rate (GFR) measurements are critical in patients with cancer. A variety of methods are used to calculate the estimated GFR. The aim of this study is to investigate whether there is a correlation between these methods and oncologic outcomes according to the stage and treatment agents.

Methods: A total of 153 patients were retrospectively recruited. All GFR measurement methods was determined in all patients, before the first cycle of chemotherapy and before the subsequent administrations.

Results: In the study population $40 \%$ of whom received platinum-based chemotherapy. In this group, overall survival was statistically significant in patients with a CKD-EPI creatinine value of 65 or greater ( $p: 0.023$ ). When we separated the arms according to the stage, there was no relationship between CKD-EPI Cystatin $C$ and progression-free survival in metastatic patients (p: 0.13). In the non-metastatic group, median DFS was 7 months and OS was 13.9 months in patients with CKD-EPI Cystatine C level above 45 (p:0.005).

Conclusions: Both CKD-EPI creatinine and CKD-EPI cystatin C were significantly associated with overall survival and diseasefree survival in patients receiving platinum-based chemotherapy. When assessed according to the stage, there was a general survival relationship with CKD-EPI cystatin C in the non-metastatic group and in the other groups there was no significant correlation with the estimated GFR measurements.
\end{abstract}

Keywords: estimated glomerular filtration methods, chemotherapy, overall survival

() 2019 by the authors; licensee MEDITAGEM Ltd., Turkey. This article is an open access article distributed under the terms and conditions of the Creative Commons Attribution License (http://creativecommons.org/licenses/by/4.0/). 


\section{ÖZ}

Amaç: Glomerüler filtrasyon hızı (GFR) ölçümleri kanser hastalarında kritiktir. Tahmini GFR'yi hesaplamak için çeşitli yöntemler kullanılır. Bu çalışmanın amacı, bu yöntemler arasında bir korelasyon olup olmadığını araştırmak ve onkolojik sonuçların evre ve tedavi ajanlarına göre değişip değişmediğini araştırmaktır.

Metot: Toplam 153 hasta retrospektif olarak tarandı. Tüm hastalarda kemoterapi tedavisinin 1. Siklusu öncesi ve sonraki kemoterapi sikluslarından önce tüm GFR ölçüm metodları hesaplanarak kaydedildi.

Sonuçlar: Çalışma populasyonundaki hastaların \%40’ platin bazlı kemoterapi aldı. Bu grupta CKD-EPI kreatinin değeri 65 ve üzerinde olan hastalarda genel sağkalım istatistiksel olarak anlamlıydı (p:0,023). Kolları evreye göre ayırdığımızda metastatik hastalarda CKD-EPI sistatin C ve progresyonsuz sağkalım arasında istatistiksel olarak anlamlı ilişki bulunamadı (p:0,13). Metastatik olmayan grupta CKD-EPI sistatin C seviyesi 45'in üzerinde olan hastalarda ortanca DFS 7 ay ve ortanca OS 13,9 ay olarak bulundu (p:0,005).

Tartışma: Platin bazlı kemoterapi alan hastalarda hem CKD-EPI kreatinin hem de CKD-EPI sistatin C genel sağkalım ve hastalıksız sağkalım ile anlamlı olarak ilişkili bulundu. Evrelere göre değerlendirildiğinde, metastatik olmayan grupta CKDEPI sistatin C ile genel sağkalım arasında anlamlı ilişki bulunmuş olup, diğer gruplarda tahmini GFR ölçüm metotları ile anlamlı korelasyon bulunmadı.

Anahtar kelimeler: tahmini glomerular filtrasyon metotları, kemoterapi, genel sağkalım

\section{INTRODUCTION}

Recently, depending on the improvements in cancer treatment, life expectancy of cancer patients increasing. However, this increase in lifetime is encountered more frequently with treatment complications. One of these is kidney failure, especially in patients who have been treating with cisplatin-based chemotherapies. Kidney damage is encountered in 15\% -50\% cancer patients during their chemotherapy $[1,2]$. For this reason, renal functions should be monitored closely, especially in patients receiving platinum-based therapy [3].

Exact calculation and determining of the glomerular filtration rate (GFR) is one of the most important criteria to calculate the dosages of chemotherapeutics in cancer patients, according to chemotherapeutics narrow blood level range. Unfortunately, we do not have satisfactory calculation methods excluding the invasive GFR calculating methods in oncology practice [4]. Direct measurement of GFR methods are the gold standards such as clearance of chromium-51 EDTA (51Cr-EDTA), inulin clearance, but these methods needs administration time, necessitate high expertise and have higher cost to use each patients in daily routine [5]. In this study, we performed GFR measurement methods and correlations before and after treatment in cancer patients receiving platinum-based and non-platinum based chemotherapy and we compare these methods with oncologic outcomes in patients actively receiving cancer chemotherapy.

\section{MATERIALS AND METHODS}

We retrospectively enrolled 153 patients who received systemic chemotherapy in our medical oncology clinic. All GFR measurement methods were followed before chemotherapy and during chemotherapy. Eligibility criteria included age $\geq 18$ years, Eastern Cooperative Oncology Group (ECOG) performance status 0-2 and serum creatinine level $\leq 1.2 \mathrm{mg} / \mathrm{dl}$. The exclusion criteria were acute or chronic renal injury, any contraindication for chemotherapy, poor performance status, uncontrolled diabetes or heart failure.

All patients had pre-treatment and post-treatment serum creatinine, cystatin c, eGFR levels according to CockcrauftGault, MDRD and CKD-EPI were calculated as referenced before [4,5]. Blood samples were taken at least 8 hours after fasting. The serum creatinine reference range was 0.51-0.95 $\mathrm{mg} / \mathrm{dl}$ for females and 0.67-1.17 for males. The serum cystatin C reference range was $0.52-0.97 \mathrm{mg} / \mathrm{dl}$.

\section{Statistics}

All statistical analyses were done with the SPSS 18.0 statistical software program (SPSS, Chicago, IL). Data with normal distribution were analyzed using unpaired $t$ test. Mann-Whitney $U$ test was used for analyzing abnormal distributed data. Correlations were studied using Spearman's rho test. Before and after values were analyzed 
Table 1. General characteristics of patients

\begin{tabular}{|c|c|c|c|}
\hline General Characteristics & Number (\%) & Pre-Treatment, IR/SD & Post-Treatment, IR/SD \\
\hline Female & $61(40 \%)$ & & \\
\hline Male & $92(60 \%)$ & & \\
\hline Cisplatin & $31(20 \%)$ & & \\
\hline Carboplatin & $31(20 \%)$ & & \\
\hline \multicolumn{4}{|l|}{ Stage } \\
\hline Early & $72(47 \%)$ & & \\
\hline Local advance & $26(17 \%)$ & & \\
\hline Metastatic & $55(36 \%)$ & & \\
\hline Median OS, months & & & $9.6(1.3-40)$ \\
\hline Median PFS, months & & & $6.3(1.3-39)$ \\
\hline Serum Creatinine, mg/dl & & $0.86(0.2)$ & $0.97(0.4-7.1)$ \\
\hline Serum Cystatin C, mg/L & & $1.06(0.3)$ & $1.01(0.4-3.7)$ \\
\hline MDRD & & $90(21)$ & $91(28)$ \\
\hline Cockcrauft-Gault & & $92(31)$ & $93.5(33)$ \\
\hline CKD-EPI, creatinine & & $91(21)$ & $90(24)$ \\
\hline CKD-EPI, cystatin & & $80(27)$ & $74(32)$ \\
\hline
\end{tabular}

IR: interquartile range, SD: standard deviation, CKD-EPI: Chronic Kidney Disease Epidemiology Collaboration equation, MDRD: Modification of Diet in Renal Disease

CKD EPI Creatinine changes during chemotherapy

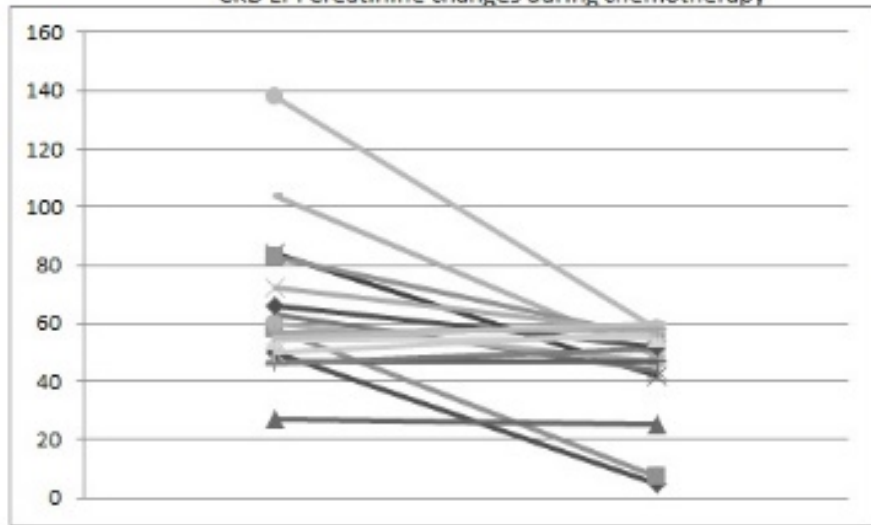

CKD EPI cystatin C changes during chemotherapy

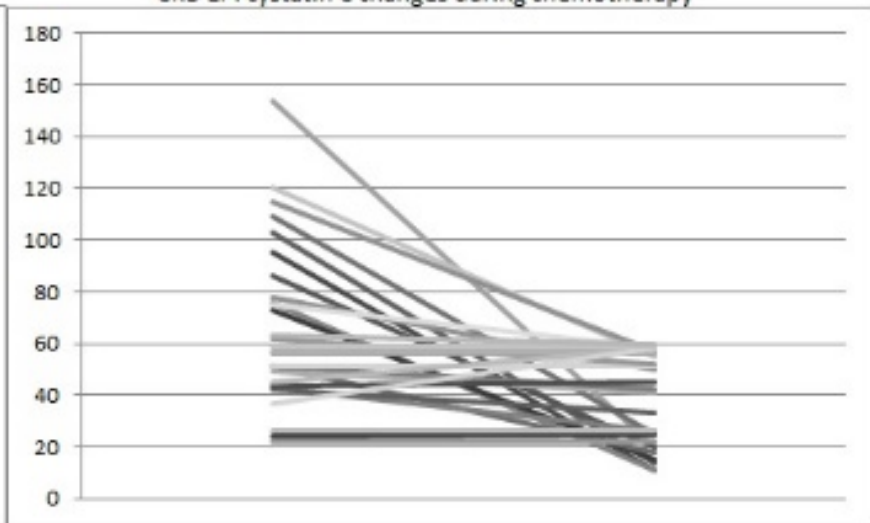

Figure 1. CKD EPI changes in patients who had deteriorated serum creatinine and cyctatin C with chemotherapy

with Paired-t test. Cut off values were calculated with ROCcurve analyses. Overall survival was tested with KaplanMeier and Cox regression analysis. All $P$ values were calculated as two tailed. The $P$ values under 0.05 were considered as statistically significant.

Informed consent was obtained from all patients before the treatment. This study was approved by The Ethics Committee of the Sakarya University Medical Center.

\section{RESULTS}

\section{Patients Clinical Features}

The mean age of the patients included in the study was 60 years. Of these patients 59 had lung cancers, 31 had breast cancers and 63 had gastrointestinal cancer. According to the standard chemotherapy regimens used in clinical practice for the different tumors, 31 (20\%) patients were treated with cisplatin, 31 (20\%) with carboplatin and remaining 91 (40\%) patients were treated non-platin regimens. General characteristics of patients were presented in Table 1. Mean serum creatinine level before treatment was $0.86 \mathrm{mg} / \mathrm{dl}$, the median seum cystatin C level was $1.06 \mathrm{mg} / \mathrm{dl}$. At the end of treatment the median serum creatinine level was 0.90 $\mathrm{mg} / \mathrm{dl}$, the median serum cystatin C level was $1.23 \mathrm{mg} / \mathrm{dl}$. At base line, 14 patients (9\%) had elevated serum creatinine levels and they received chemotherapy according to guidelines dosage adjustment recommendations.

Only one patient of these 14 patients had acute renal deterioration during chemotherapy, at the end of chemotherapy $18(11.7 \%)$ patients had elevated serum creatinine. In the study group $19 \%$ of patients had elevated cystatin C levels at base line and $32 \%$ of patients had elevated cystatin $C$ levels following the treatment. According to the CKD EPI calculation of these patients were presented in Figure 1.

During the chemotherapy period only one patient need hemodialysis and progressed to end stage renal disease. 


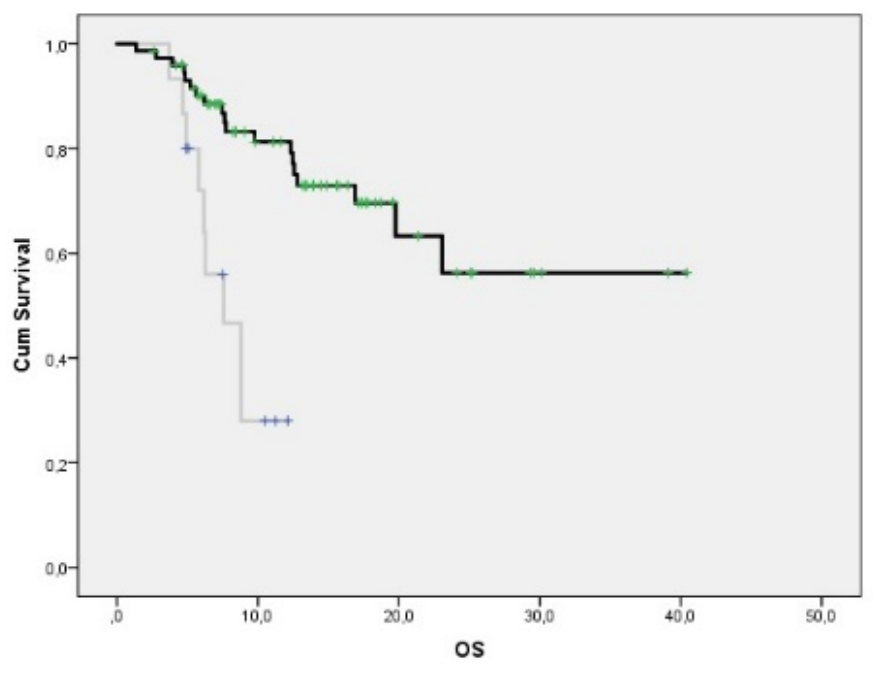

(a)

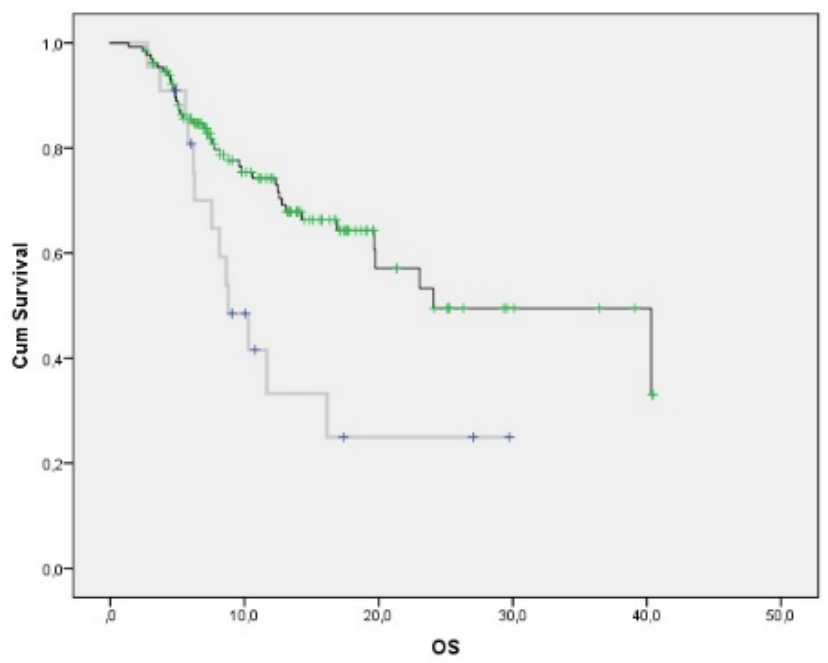

(b)

Figure 2. a) CKD EPI Cystatin C for value of 45 and OS differences in lower and higher of this value, b) CKD EPI Creatinine for value of 65 and OS differences in lower and higher of this value

Table 2. Survival outcomes and correlation with cutoff values of CKD EPI calculation

\begin{tabular}{|c|c|c|c|c|c|c|}
\hline e-GFR method & OS, months & & P value & $\begin{array}{l}\text { DFS/PFS, } \\
\text { months }\end{array}$ & & Pvalue \\
\hline & $<45$ & $>45$ & & $<45$ & $>45$ & \\
\hline CKD EPI Cystatin C (metastatic) & 6.8 & 7.7 & 0.14 & 4.8 & 5.2 & 0.13 \\
\hline CKD EPI Cystatin C (nonmetastatic) & 6.3 & 13.9 & 0.005 & 5.5 & 7.0 & 0.005 \\
\hline & $<65$ & $>65$ & & $<65$ & $>65$ & \\
\hline CKD EPI Crea. (metastatic) & 7.8 & 7.7 & 0.36 & 7.3 & 4.9 & 0.75 \\
\hline CKD EPI Crea. (nonmetastatic) & 9.3 & 13.3 & 0.64 & 5.3 & 7.5 & 0.69 \\
\hline
\end{tabular}

OS: overall survival, DFS: disease free survival, PFS: progression free survival, Chemo: Chemotherapy, Crea.: Creatinnie, 45: cutoff point of CKD EPI cystatin C, 65: cutoff point of CKD EPI creatinine

In Cox-Regression model, all estimating GFR methods were analyzed with adjusting the other parameters such as sex, age, comorbidities and CKD-EPI cystatin C and creatinine levels following the chemotherapy were significantly correlated with overall survival ( $p: 0.007$ and p: 0.005, respectively). Baseline values of all estimating GFR methods (MDRD, CKD EPI and CGE) did not show significant correlation with OS as well as after treatment values of MDRD and CGE.

In patients who had been treated with platinums, according to CKD-EPI calculation with cystatin c there was a significant cut off value with OS in the ROC-curve analyses with $70 \%$ sensitivity and $90 \%$ specificity for cutoff 45 (p: 0.005). Similar to platinum arm, there was a significant relationship between CKD-EPI Cystatin C with overall survival in the nonplatinum arm (p:0.045).Similar to CKD-EPI Cystatin C, we found a statistically significant relationship between CKDEPI creatinine with OS (75\% sensitivity and $90 \%$ specificity for cutoff point 65, p:0.001). In the platinum arm, there is an overall survival benefit was found with CKD-EPI creatinine 65 and above (p:0.023). In the non-platinum arm there was no significant relationship between CKD-EPI creatinine levels and OS. The OS differences between the groups according to the CKD EPI values were presented in Figure 2.

We also analyzed CKD EPI levels for stages and DFS or PFS and the results were showed in Table 2. Briefly, overall survival was statistically higher in the non-metastatic group with a CKD-EPI creatinine value of 45 and above.

When we separated the arms according to the stage, there was no relationship between CKD-EPI Cystatin C and progression-free survival in metastatic patients ( $p: 0.13)$. The median DFS was 5.5 months and OS was 6.3 months in the non-metastatic group for CKD-EPI Cystatin C 45 and below the levels. In the same group, median DFS was 7 months and OS was 13,9 months in patients with CKD-EPI Cystatine C level above 45 (p:0.005).

In the non-metastatic group, DFS was 5.3 months and OS was 9.3 months for those with a CKD-EPI creatinine value of 65 and below. When CKD-EPI creatinine level was compared to the group above 65, there was no statistical difference for DFS and OS (p:0.69 and p:0.64, respectively). Similarly, in patients with metastatic disease, there was no relationship 
between CKD-EPI creatinine value and PFS or OS (p:0.75 and p:0.36, respectively).

\section{DISCUSSION}

In this study, we investigated the correlation of estimated GFR measurement methods (CKD-EPI, MDRD and CockcroftGault equation) with oncological outcomes in patients who were receiving cancer chemotherapy. We found that estimated CKD-EPI cystatin C and creatinine levels were significantly correlated with overall survival but not disease free survival or progression free survival. Baseline values of all estimating GFR methods (MDRD, CKD EPI and CGE) cannot predict oncological outcomes as well as after the treatment values of MDRD and CGE except CKD EPI methods.

Evaluation of kidney functions for calculating sufficient dose in cancer treatments that have been treated with nephrotoxic agents is very important. Exogenous markers, especially inulin clearance remains the gold standard method for measuring GFR; however it is expensive, inconvenient and difficult to measure. Therefore, GFR measurement methods based on serum creatinine levels are widely used today. Estimated GFR methods have been created for non-oncological patient population especially occurred with patients had chronic kidney disease. The usefulness of these methods in oncology practice has limited data [6].

We know that CGE was the most commonly used eGFR methods in internal medicine practice but, muscle mass and ethnicity should affect the serum creatinine, and MDRD was developed. Recently CKD EPI equation was created after epidemiologic studies [7,8]. The CKD-EPI equation is now accepted the most accurate estimating method for GFR prediction $[9,10]$. Matsushita et al. investigated more than 1 million adults from 25 general population cohorts and they found that CKD EPI had better outcomes than MDRD to predict mortality but these populations had especially chronic kidney disease or end stage renal disease [11]. One of the recent studies about this topic published by Janowitz et al. They investigated about 2500 patients who had GFR results calculated with chromium-51 (51Cr) EDTA excretion in cancer patients. Cr-EDTA GFR results had been compared with eGFR methods and they found CKD-EPI was the most accurate predicting model for GFR calculation [12]. Rhee et al also investigated $3 \mathrm{GFR}$ methods in cancer patients treated with platins. They founded MDRD and CKD EPI were more accurate than CGE equation in Korean population [5]. To our knowledge there is no study in the literature investigated the relation with oncologic outcomes and eGFR methods. Our study has some new findings additionally to literature, first decreasing CKD EPI equation with cystatin C levels significantly correlated with decreased overall survival in cancer patients during chemotherapy irrespective of stage and chemotherapeutic drugs. Decreasing CKD EPI creatinine levels has significant correlation with overall survival only patients treated with platin based regimens.

There are some limitations to our analysis. First, we used a small number of patients, including lung, breast and gastrointestinal cancers. On one side, a group of patients were treated with a single agent chemotherapy, while a group of patients were treated with a triple agent. On the other side, the cancer of the patients included in the study is heterogeneous. Secondly, we did not analyze comorbid diseases associated with our patients and the use of drugs to cause renal dysfunction.

In our conclusion, consistent with the literature CKD EPI equation of GFR has more correlation with oncological outcomes during cancer chemotherapy. Additionally, when we are following up our patients during chemotherapy, cyctatin C based CKD EPI equation should be check in patient who will treat with platin based regimens and nonmetastatic stage.

\section{DECLARATION OF CONFLICT OF INTEREST}

The authors received no financial support for the research and/or authorship of this article. There is no conflict of interest.

\section{REFERENCES}

1. Launay-Vacher V. Epidemiology of chronic kidney disease in cancer patients: Lessons from the IRMA study group. Semin Nephrology. 2010;30:548-556.

2. Janus N, Launay-Vacher V, Byloos E, et al. Cancer and renal insufficiency results of the BIRMA study. $\mathrm{Br} J$ Cancer. 2010;103:1815-1821.

3. Patterson WP, Reams GP. Renal toxicities of chemotherapy. Seminars in Oncology. 1992;19(5):521528.

4. Haddadin Z, Lee V, Conlin C, Zhang L, Carlston K, Morrell G, Kim D, Hoffman JM, Morton K. Comparison of performance of improved serum estimators of glomerular filtration rate (GFR) to $99 \mathrm{mTc}$-DTPA GFR methods in patients with hepatic cirrhosis. J Nucl Med Technol. 2017;45(1):42-49. 
5. Rhee J, Kwon JM, Han SH, Kim SH, Park CH, Jeon JH, Cho JT, Lee EK, Kim SM. Cockcroft-Gault, Modification of diet in renal disease and chronic kidney disease epidemiology collaboration equations for estimating glomerular filtration rates in cancer patients receiving cisplatin-based chemotherapy. Kidney Res Clin Pract. 2017;36(4):342-348.

6. Ainsworth NL, Marshall A, Hatcher $\mathrm{H}$, et al. Evaluation of glomerular filtration rate estimation by Cockcroft-Gault, Jelliffe, Wright and Modification of Diet in Renal Disease (MDRD) formulae in oncology patients. Ann Oncol. 2012;23:1845-1853.

7. Jacobs DR, Jr, Murtaugh MA, Steffes M, Yu X, Roseman J, Goetz FC. Gender- and race- specific determinationof albumin excretion rate using albumin-to -creatinine ratio in single, untimed urine specimens: the Coronary Artery Risk Development in Young Adults Study. Am J Epidemiology. 2002;155:1114-1119.

8. Chung BH, $\mathrm{Yu} \mathrm{JH}, \mathrm{Cho} \mathrm{HJ}$, et al. Comparison of estimating equations for the prediction of glomerular filtration rate in kidney donors before and after kidney donation. PLoS One . 2013;8:e60720.
9. Matsushita K, Mahmoodi BK, Woodward M, et al. Comparison of risk prediction using the CKD-EPI equation and the MDRD study equation for estimated glomerular filtration rate. JAMA. 2012;307:1941-1951.

10. Wang X, Luo Y, Wang Y, et al. Comparison of associations of outcomes after stroke with estimated GFR using Chinese modifications of the MDRD study and CKD-EPI creatinine equations: results from the China National Stroke Registry. Am J Kidney. 2014;63: 59-67.

11. Kos FT, Sendur MAN, Aksoy S, et al. Evaluation of the renal function using cystatin $\mathrm{C}$ level in the patients receiving cisplatin-based chemotherapy. Renal Failure. 2013;35(5):705-710.

12. Janowitz $T$, Williams EH, Marshall $A$, Ainsworth $N$, Thomas PB, Sammut SJ, Shepherd S, White J, Mark PB, Lynch AG, Jodrell DI, Tavare S, Earl H. New model for estimating glomerular filtration rate in patients with cancer. J Clin Oncol. 2017;35(24):2798-2805. 